\title{
Teacher training in heritage education: good practices for citizenship education
}

\author{
José María Cuenca-López (10 ${ }^{1 凶}$, Myriam J. Martín-Cáceres ${ }^{1} \&$ Jesús Estepa-Giménez ${ }^{1}$
}

Education of citizens to understand, address and resolve current social and environmental issues calls for a new professional profile that is more reflective, investigative, and critical of the teaching staff and which modifies the predominant, more traditional teaching methodologies. For this reason, we consider it essential that future teachers responsible for all subjects in which heritage is a relevant educational component should have appropriate training in these key concepts, in relation to heritage, emotions, identities, citizenship, and the approach to relevant socio-environmental problems. The study developed here analyses different end-of-degree projects (undergraduate and master's degrees) carried out by teachers in initial training for Primary and Secondary Education. In their training process, they have addressed different criteria that are considered key to carry out didactic proposals for citizenship education based on heritage, from the perspective of determining good practices in the teaching and learning processes of the social sciences. The approach of this research is characterized by a qualitative methodology, through a documentary study, in which the materials produced by teachers in initial training are examined by analytical categories of this study: Why teach about heritage? What is taught about heritage? How is it taught? What relations are established between emotional intelligence and heritage? What relationships are established between territorial intelligence and heritage? In this study, the importance of the connection between educational research and innovation processes for the training of teachers in the field of heritage education with respect to education for citizenship has been highlighted. The connections of heritage with citizenship education and the potential involved in working on emotional and territorial intelligence have been highlighted too. However, it has been evidenced that it is necessary to go much further into the implementation of the approach to territorial intelligence in which the citizenry should be involved through shared management of heritage.

\footnotetext{
${ }^{1}$ University of Huelva (COIDESO Research Centre), Huelva, Spain. ${ }_{\text {email: jcuenca@uhu.es }}$
} 


\section{Educational research and innovation in teacher training: Heritage education and citizenship education}

eritage has emerged as a key element in social sciences teaching (Feliú and Hernández-Cardona, 2011; Fontal and Ibáñez, 2017; Molina et al., 2016; Prats, 2011; Wang, 2019) as an objective, as content and an educational resource for the development of socially relevant competences in the formation of participatory and active citizenship (López-Facal et al., 2017; No et al., 2017). The concepts of heritage and heritage education have already been defined in many other works, under the premises of a holistic, systemic, symbolic-identity and social vision, where didactic proposals of a transdisciplinary, participatory and innovative nature prevail; in short, configured as an alternative to the predominant traditional didactic model in regulated education (Estepa, 2019). Thus, the purpose of heritage education would lie in the training of a committed and active citizenry that is equipped to understand, address and resolve current social and environmental issues (Cuenca et al., 2020).

Educational research allows us to approach the problems of education, detecting good practices, but also the obstacles that hamper the development of teaching and learning processes that we consider desirable. Innovation allows us to approach these obstacles, seeking solutions to the difficulties that the research has revealed, designing proposals that must be tested and analyzed (rethinking the objectives, content, methodological strategies, resources, and evaluation criteria), to then develop new research processes based on the experiments carried out.

But, in addition, in the teacher training process, it would be important to approach the areas that are worked on from this double standpoint of educational research and innovation. These aspects are key factors for teaching and learning so that both processes must always be connected. In other words, the results of the research have to revert into the activity of the teaching staff, in order to achieve the improvement of education, producing real and effective feedback. So, the educational research that we consider relevant is that which can contribute to the real transformation of education through innovation; and innovation can provide an excellent field for educational research (Estepa, 2019).

In this line, several studies have already been carried out that show the importance of teacher training of this interaction between research and educational innovation. Thus, Estepa and Travé (2012), in the case of teachers in initial training for primary education, examined how working with the research area of current and historical societies, under criteria similar to those set out in the HETEIC project ${ }^{1}$, greatly contributes to professional development and didactic and social transformation, as well as improvement of the school environment.

Fuentes et al. (2020), presented a study in which they verified the relevance of working with active, dynamic, and participatory methodologies in the initial training of teachers, with a review of the key contents under study, to promote change in the teachinglearning processes, aimed at education for democratic citizenship. This necessary preparation of future teachers for civic and democratic training has been evidenced in various works, among which we can cite those of Darling-Hammond and Bransford (2005), Leenders et al. (2008), Hauver (2010), Molina et al. (2013), Poce et al. (2018).

Many research works have been carried out in the heritage education area that highlight the characteristics and obstacles encountered when working on heritage education in the formal sphere (Fontal and Ibáñez, 2017; Lobovikov-Katz, 2019). One of the outcomes we can highlight from this research, and which gives rise to this work, is the important capacity of heritage to connect with emotional and territorial intelligence, linking these aspects with the work on identities and citizenship, as it is the identity ties that promote greater individual and collective acknowledgment. For their part, identities, from the heritage perspective, pose a challenge for education, insofar as they are perceived as an element that allows us to value our own at the same level as those of others, that is, to work on identity from an inclusive perspective, versus egocentrism and sociocentrism. Training for citizenship, on the other hand, provides heritage with socio-educational meaning when working in the teaching and learning area (Delgado and Cuenca, 2020).

Through the contributions of research in these fields, through the analysis of different educational experiences, case studies, content analysis of didactic materials and productions of students and teachers, narrative studies, etc., innovation processes bring into play new proposals that also need to be evaluated. Thus, the studies that have been carried out lead us to emphasize the revision of the contents that are the object of teaching and learning, both in context selection and organization.

It is important to choose contents that are truly connected with the premise of working towards the relevant socio-environmental issues of today and which, once selected, are approached organized in significant nuclei to be worked upon as problems that also connect with the interests of the students. Not an easy task, but it is an exciting challenge. The aim is not to simplify the educational curriculum or only work on what the students find interesting. It is more about making current issues also relevant for education, analyzing them, thoroughly examining their social complexity, valuing them, making decisions about them, and looking for possible solutions (García-Pérez, 2019).

Of course, innovative proposals also have an important methodological component. The didactic approach to these contents has to work on the basis of interactive and participatory proposals, through the use of strategies linked to problemsolving and school research (Estepa, 2019), project-based working, and active learning methods (Younghoon, 2019). In this sense, it is also necessary to be able to use resources that facilitate this participation and interactivity, for which technology is usually good support, although this, by itself, does not imply an innovation if it is not accompanied by a session scheduled and organized by the teachers for the pupils, with their protagonism in the processing of the contents and development of the activities.

In short, this entire process of innovation in the educational treatment of heritage and identity is focused on the development of competencies aimed at training critical and responsible citizens. Innovation, in this field of heritage education, must obviously connect with social and civic competence, but it should not be overlooked that other competencies can also be addressed through this line of work, including digital competence, sense of initiative, and enterprising spirit, as well as awareness and cultural expressions (Domínguez-Castillo, 2015).

Starting from these educational research and innovation processes, and their connections, the initial teacher training must be developed, taking into account the aforementioned aspects, both at a general level, and in the specific case of training oriented to education for the citizenship and heritage education, in our case. In this sense, we understand research and innovation as linked to the development of the curriculum and the treatment of curricular problems, which, in the case of teachers in training, where there is no practice or it is limited to the practicum period, would be problems for practice focused on curriculum design (Estepa, 2019).

From this perspective, the aspects that we consider key for the development of good practices in citizenship education through heritage are based on curricular issues upon which it is necessary to reflect during the teacher training processes: Why teach heritage? What is taught about heritage? How is it taught? What relations are established between emotional intelligence and 
heritage? What relationships are established between territorial intelligence and heritage? This set of questions takes into account all the curricular elements (why, what, how) with heritage as the structuring axis, as its polysemic character allows it to be an objective, content, and resource while promoting a desirable citizenship education.

All these issues allow us to approach a desirable vision for the connection between heritage education and citizenship education (Delgado and Cuenca, 2020). First of all, the concept of heritage education to be addressed by future teachers must be clarified (through the first three questions). Along the same lines, two relevant aspects to determine the connections between heritage and citizenship consist, on the one hand, of emotional education as a factor for the development of sociocultural competencies in learning processes, linked to socio-cultural motivations, values, and feelings (Bisquerra and Pérez, 2007) and, on the other hand, territorial intelligence to manage the links between landscapes, the environment, and citizens (Girardot, 2013).

This way, from the perspective advocated in the HETEIC project, the training of teachers focused on the development of good practices for citizenship education through heritage sets out from configuring a vision of heritage of a holistic and symbolicidentitary nature, from a sociocritical standpoint, which allows a complex integration of the heritage content under study, through its functional, spatial, temporal and social contextualization. The teaching and learning processes must develop multidirectional communication through activities of a systemic nature and leveraging multiple resources, both traditional and innovative, and the use of new educational technologies (Jiménez-Pérez et al., 2010).

Likewise, the connections established between emotional intelligence, territorial intelligence, and heritage education, in the sense of what has been stated above, allow a new vision to be given to citizenship training. Thus, the educational treatment of emotions should focus on interactions with the social context of the students, with an adaptation to the environment that allows problems to be solved in a real and flexible way, oriented towards the multiplicity of identities and respect for their diversity. In relation to territorial intelligence, it would be based on a cultural vision of the landscape, in which the identity and social and natural perceptions of the individual are valued, as well as a sense of the environment linked to the concept of post-development and the theory of degrowth, overcoming the idea of sustainable development. In this sense, global citizenship and commitment to justice must be conceived, respecting and valuing interculturality and the concept of interterritoriality (Cuenca et al., 2020).

\section{Methods}

The approach of this research is characterized by a qualitative methodology, within the interpretive paradigm (Bisquerra, 2016; Flick, 2018), through a documentary study, in which the materials produced by teachers in initial training are examined, after addressing the aspects considered as key and that make up the categories of analysis of this study (McCulloch, 2004; Scott, 2006).

The basic aim of this research consists of assessing the impact that heritage education entails for citizenship education and the role that it plays, together with the development of emotional and territorial intelligence, in initial teacher training within the

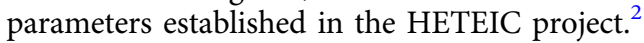

To this end, 38 final degree projects were analyzed, both undergraduate (TFG) and master's (TFM), of various teachers in initial training for primary and secondary education, in which heritage education was addressed in the line previously expounded, after having worked on aspects related to emotional and territorial intelligence through heritage oriented to citizenship education in different subjects of their professional studies. The criteria established for the selection of these documents have been that they have been prepared within the framework of the HETEIC project, within the teacher training qualifications in which they have been carried out, addressing the aspects previously explained.

These works (Table 1; Annex I) are presented within the framework of three-degree courses at the University of Huelva (Spain), in which subjects related to heritage education have been taught from the perspective advocated here and set out in the HETEIC project, aimed at the formation of critical, participatory and socially committed citizens. These qualifications are the Degree in Primary Education (GEP), Master's Degree in Teacher Training for Secondary Education, specializing in Social Sciences, Geography and History (MAES), and the Master's Degree in Research in Science Teaching and Learning, in the Didactics itinerary of Social Sciences (IEAC), taught over five academic years $(2015 / 16,2016 / 17,2017 / 18,2018 / 19$, and 2019/20), in which the HETEIC project has been active and the teacher training processes in this line were developed.

To this end, a table of categories was designed (Table 2; Annex II), based on the research carried out in the HETEIC project (Cuenca et al., 2020), through which the treatment that these future teachers have given to the key issues that we have previously determined is analyzed and assessed: Why teach about heritage? What is taught about heritage? How is it taught? What relations are established between emotional intelligence and heritage? What relationships are established between territorial intelligence and heritage?

These questions are configured as study categories and each one is structured in different subcategories, through which the most relevant aspects to the analysis process are defined more specifically. Finally, each subcategory is divided into different indicators structured as progression hypotheses and ordered from their simplest characteristics to the most complex or desirable (Jiménez-Pérez et al., 2010) which allow the development of a systematic and rigorous analysis of information sources.

Instruments of these characteristics have already been used in previous studies (Cuenca, 2004, Lucas and Delgado, 2018), in the case of research focused on heritage education and teacher training, which have already shown their efficacy and versatility in analyzing different sources of information, particularly in the case of documentary studies such as the one presented in this work.

\section{Results and discussion}

As indicated, 38 documents have been analyzed, as a result of the end-of-degree work of teachers in initial training, once they had completed their undergraduate or master's studies. Of these works, 27 of them belong to final master's degree projects (17 from the master's degree in Research in Science Teaching and Learning and 10 from the master's degree in Teacher Training for Secondary Education), compared to 11 that make up the end of studies in the Degree in Primary Education teacher training (Annex I).

As can be seen, presenting works in the field of heritage education is more commonplace in master's degrees, where the specificity of the training is much greater, with specific subjects in this sense in the case of IEAC or very specific work proposals in MAES. In the training for the Teaching Degree in Primary Education, although specific aspects related to heritage education are also worked on, the great breadth of lines open to carry out the end-of-degree projects means that the number of future teachers who choose these subjects is much lower, despite the number of people enrolled in these degrees being substantially higher compared to those taking the master's degrees. 


\section{Table 1 Documents under study.}

\section{ID Work}

I am beauty you are beauty! Heritage: Analysis tool for current stereotypes.

2 An alternative proposal for: Rome, owner of the world.

3 Coexistence between Christian, Muslim and Jewish women, art, and society in Al-Andalus. A didactic proposal for CSE (Compulsory Secondary Education) year 2

4 The Roman way of life. Urban and domestic designs. Women's role in the domestic economy in Roman Andalusia.

5 Heritage and ECE (Early Childhood Education): Bibliographic review of experiences working in the educational area.

6 Didactics of social sciences and video games. Analysis of experimenting with the game Dominations for learning about Mesopotamian cultures.

7 Heritage education and special education: Working on emotions through heritage with people with special educational needs.

8 The Alcazar of Seville.

9 Do I know my town? A didactic proposal to teach heritage in Primary Education.

10 Didactics of heritage: Escacena, our jewel.

11 Didactics of heritage: Huelva between the $19^{\text {th }}$ and $20^{\text {th }}$ centuries. The English legacy.

12 Al-Andalus, our legacy.

13 Didactics of social sciences through video games: Research and experimentation with game Assassin's Creed Origins for possible didactic proposal on the teaching of heritage and culture of Ancient Egypt.

14 Analysis of the conceptions of ECE pupils about heritage and interculturality.

15 Conceptions of heritage and identity in primary school pupils.

16 How to educate in interculturality through heritage education: Case study.

17 Conceptions of primary education pupils regarding heritage.

18 Heritage and attention to diversity: Bibliographic review study.

19 Review of a teaching unit: Roman civilization.

20 Roman games. An alternative proposal for teaching Roman civilization in CSE year 1.

21 Social organization in ancient Rome. A didactic proposal for CSE year 1.

22 The heritage of Bollullos Par del Condado.

23 Platero and I as a resource for teaching and learning about the heritage of Moguer.

24 My heritage, your heritage, our heritage.

25 Conceptions and emotions around heritage in ECE: Analysis of an educational proposal.

26 Getting to know our roots. An educational experiment in the secondary school of Saltés, Punta Umbría.

27 From the Islamic conquest of the Iberian Peninsula to the capture of Granada. Analysis of the Al-Andalus teaching unit and alternative proposal.

28 Heritage as part of us.

29 Working on the English legacy in primary education: A vestige that still persists in every corner of Huelva.

30 Heritage and emotions in primary education.

31 Storytelling in heritage education: Analysis of didactic proposals in early childhood education.

32 Learning about local heritage at the secondary school stage: A study in CSE year 4.

33 Comparative analysis of heritage elements in the curricula of six autonomous communities.

34 How is heritage presented in primary education textbooks with LOE and LOMCE?

35 Early Childhood Education: A comparative view of heritage in Colombia and Spain. Bibliographic review study.

36 Ecology, environment and entertainment. A different way of understanding education and sustainable development in Ayamonte.

37 Al-Andalus, a look at heritage: Analysis and alternative didactic proposal.

38 Heritage education, ICT, and family involvement. Before and after the state of alarm.

\section{Table 2 Analysis categories.}

\section{Categories}

I. Why teach?

II. What is taught?

III. How is it taught?

IV. What relations are established between emotional intelligence and heritage?

V. What relationships are established between territorial intelligence and heritage?

\section{Subcategories}

1. Towards what approaches is the proposal oriented?

2. What is the aim of the education process?

3. Why is something heritage?

4. What heritage is taught?

5. What degree of interrelation is there between the heritage that is taught?

6. How are the contents integrated?

7. In what way are the contents contextualized?

8. What is the presence of heritage in the educational schedule?

9. What roles do the teachers and pupils play?

10. What type of activities are carried out?

11. What resources are used?

12. What dimensions of learning are established?

13. What skills are developed through emotional intelligence?

14. What are the constituent elements of identity/heritage?

15. What vision of landscape is worked upon?

16. What vision of citizenship is worked upon?

17. What vision of the environment is worked upon?

18. What connection with the surroundings is approached? 
The presentation of the results is based on the treatment given by the different studies analyzed to the various categories that are established as basic in the connection of heritage education and education for citizenship and which are configured as references of the HETEIC project.

Category I: Why teach heritage? The aims of heritage teaching that are set out in the different works examined are mainly framed within the training of a critical citizenry connected with aspects related to emotions, the territory, scientific-cultural literacy, or environmental education, always within an evolutionary process that would range from a more basic vision, of an academic nature to a sociocritical vision.

Several of these works connect with the approach to relevant social issues within a sociocritical aim, as occurs, for example, in case TFM 1, linked to the analysis of gender problems through heritage, reviewing the esthetic canons in adolescence, as well as cases 3 and 4, in which educational proposals related to daily life are made from the master's degree in secondary education teacher training. The propagandist objective is not perceived in any of the documents. However, although they are scarce, it is necessary to cite some works, especially in the TFG, in which a marked academic perspective is presented (cases TFG 9 and TFG 10) in the didactic proposals that are made, which on the other hand coincides with a predominant vision in teaching and learning processes in general (Estepa et al., 2008). More abundant are the works oriented towards the conservationist aim through the teaching of heritage, which is particularly perceived in cases such as TFM 17, TFG 24, or TFM 32, in which the meaning of heritage education is conceived as more closely linked with the conservation of heritage than with its socializing value or as a key reference for citizenship education, coinciding with the results of various studies that analyze students' conceptions about heritage and its teaching (Trabajo and Cuenca, 2020).

The works that deal with visions related to scientific and cultural literacy are abundant, as this is an aspect that is usually deemed necessary within educational aims. Thus, among the many works that follow this approach, we can highlight cases TFM 8, TFM 19, or TFM 27, for the emphasis they show on the treatment of scientific and cultural content linked to heritage for citizenship education. The works focused on environmental education and territorial intelligence are much scarcer, standing out on this occasion case TFM 36, as will be specified later in category $\mathrm{V}$.

Also noteworthy are the studies focused on the importance of heritage education in the development of proposals for attention to diversity, (cases TFM 7 and TFM 18), which connect with other studies in which heritage is understood as an enhancer of socialization whereby educational designs are promoted that allow the treatment of citizenship in vulnerable groups and with other educational needs (Gómez-Hurtado, 2019; Mendioroz et al., 2019).

Category II: What is taught about heritage? Heritage visions of a holistic and symbolic-identitary nature are perceived in different works, despite the complexity of their implementation in the teaching and learning processes. However, we see cases in which the patrimony that is addressed focuses on a single heritage typology (usually historical-artistic) and on a specific historical period (for example, cases TFM 2, TFM 19, TFM 20, and TFM 21 , in the Roman world or TFM 3, TFG 12, TFM 27, and TFM 37 in the Islamic medieval period), especially in the case of the TFM related to the master's degree in secondary education teacher training, or related to monumental heritage, which addresses the treatment of a specific heritage reference such as the Alcazar of
Seville (case TFM 8) or the universal literary work Platero and I (case TFG 23). Nor should we forget to mention some documents in which the esthetic and temporal perspective, so predominant in the teaching and learning processes, is also reflected in the teachers in training, but their evolution towards identitary visions is perceived.

In this sense, it is necessary to highlight this holistic and symbolic-identitary approach in specific cases such as TFG 24 and TFG 28 or TFM 15 and TFM 26, in which identity shapes the meaning of the didactic proposals and the analyses performed, in several of them, in terms of the educational experiments carried out, always from the perspective of the interdisciplinarity of the treatment of heritage content. On the other hand, it is necessary to mention how no work sets out from the diversity criterion when determining the conception of heritage in its didactic proposals or in their analysis.

As stated earlier, the priority consideration is that of historicalartistic heritage, although the holistic vision is also noteworthy. However, the heritage type least represented in the work of future teachers is the scientific-technological heritage, and when it is worked upon it is linked with highly specific cases related to technological breakthroughs highlighting the British legacy from the extraction and trading of mining outputs (cases TFG 11 and TFG 29). Ethnological heritage particularly features in documents that approach the treatment from a more local perspective, as occurs in those cases that develop didactic proposals oriented to Primary Education, focusing on specific localities (cases TFG 9, TFG 10, TFG 22, and TFG 28).

A conception is perceived whereby innovation begins with a new selection of contents that involves an approach to socially relevant issues, integrally connecting the conceptual, procedural, and attitudinal contents from an interdisciplinary perspective. This arises in many of the works (cases TFM 2, TFM 3, TFM 4, TFM 14, TFM 16, TFM 18, TFM 20, TFM 21, TFM 26, TFM 27, TFG 30, TFM 36, TFM 37, and TFG 38), which are based on studies and experiences in which the innovative proposals focus on addressing content that is usually ignored or which is oriented to more conservative approaches, which do not question the prevailing social models (López-Arroyo, 2020). One example is the teaching of heritage in conflict (Domínguez-Almansa and López-Facal, 2017; Estepa and Martín-Cáceres, 2020), through which a complex reflection of current societies can be reached, promoting conceptual change.

Finally, in general, regarding the contextualization of the heritage contents that are presented in the works analyzed, their temporal and spatial connection predominates, in order to ensure the understanding of the elements that are the object of teaching and learning. However, contextualizations of a functional or social nature, which would allow a much more complex and nuanced interpretation of the social phenomena linked to heritage, do not appear.

Category III: How is it taught? In this category, the relationships between research and innovation are perceived more clearly, so that the educational analysis processes are connected with processes of methodological renewal and updating, tending on some occasions towards proposals for educational action-research, as is perceived in cases TFM 21 or TFM 26, for example.

In the works analyzed, it is common for heritage to be used as an objective, content, and didactic resource. However, it is difficult to overcome the predominance of the vision of heritage exclusively as a resource, an aspect that is perceived in several cases, both in future primary education teachers (cases TFG 10, TFG 22, and TFG 28) and in some in secondary education (cases TFM 19, TFM 27, and TFM 37). 
Regarding the type of activities that are designed or experienced in the didactic proposals presented, they are between a level of analytical complexity (descriptive in nature with the use of various sources of information) or systemic (predominating justifying argumentation and critical analysis). In general, the most evolved and complex activity designs are found in the works that are developed in the Master's Degree in Research in Science Teaching and Learning (cases TFM 25, TFM 26, TFM 31, and TFM 32), a qualification in which the in-depth theory-practice of heritage education is much higher.

The use of communication technology is very frequent, being incorporated in almost all cases, but the use of very specific resources can be highlighted in the case of video games for the teaching of heritage and related social content, as occurs in cases TFM 6 and TFM 13, with the teaching of Mesopotamian and ancient Egyptian culture, respectively. The use of this technology, focused on videogames (Gómez-Carrasco et al., 2020; JiménezPalacios and Cuenca, 2015) or augmented reality (Sáez-López et al., 2020), among other proposals, is demonstrating its potential as a facilitator of learning and motivator of educational processes (Gómez-Carrasco et al., 2020).

Case TFG 38 is interesting, as it reflects upon the use of different technology-focused teaching methodologies to develop teaching and learning processes in periods of confinement due to COVID-19, highlighting the support that students require from families to maintain the educational process with the necessary guarantees.

Several works have also been presented in which other resources that can be used as support for the teaching of heritage are analyzed, such as stories (case TFM 31) or the use of textbooks (case TFM 34), as priority resources by the teaching staff, in which the representation of the historical, artistic and monumental heritage predominates, together with more traditional didactic visions, as demonstrated in several previous studies (Barghi et al., 2020; Cuenca and López-Cruz, 2014). Case TFM 34, moreover, reflects upon the role of educational legislation, which determines, also taking into account the freedom of the teacher at a methodological level (GómezCarrasco et al., 2020), the contents that are the object of teaching and learning (Martínez-Rodríguez and Fontal, 2020), in a similar way to that proposed in case TFM 33, analyzing the educational curricula of different Spanish autonomous communities or the comparisons between the situations that occur in Spain and Colombia in this area (case TFM 35).

Category IV: What relations are established between emotional intelligence and heritage? The treatment of emotions is considered a key element in citizenship training through heritage education (Munilla and Marín, 2020). This aspect is evident in several of the works prepared by future teachers, as seen in the object of work in cases TFM 7, TFM 25, and TFG 30, but it is also present in many others.

In this sense, we should also cite the works in which interculturality and identitary multiplicity are addressed as an educational reference, as detected in cases TFM 14 and TFM 16. However, the most frequent finding is that the works address empathy and social responsibility from the affective-emotional or territorial perspective (cases TFG 9, TFG 10, TFG 11, TFG 22, or TFG 24), much simpler to propose than the assessment, respect, and acknowledgment of the diversity of existing cultural identities (Pinto, 2017).

Few works address the social dimension of learning, in relation to the emotional components, the analysis of the students' conceptions being more common, to approach the cognitive dimension through the contents and information they develop (cases TFM 14, TFM 15, TFM 17, and TFM 25). Something similar occurs with the treatment of emotional skills, which are usually linked with interpersonal intelligence, rather than with adaptation to the environment, in which the resolution of socioenvironmental issues would be sought in a real and flexible way (a situation that was only perceived in case TFM 36).

Category V: What relationships are established between territorial intelligence and heritage? The category that is least reflected in the documents analyzed is the one related to the connection between territorial intelligence and heritage education. Territorial intelligence is a very complex concept that has hardly been worked on in education. Within the works reviewed, this relationship is clearly seen in case TFM 36, in which a proposal focused on sustainable development is approached from an ecological perspective, although the meaning of post-development theory is not perceived in any case (Escobar, 2005).

The perspective of landscape in the educational field is addressed in various cases (TFM 32), although focused on a more local vision. The cultural vision of heritage, in which social and natural aspects are connected, is quite scarce, more closely linked to a conservationist vision, in which the heritage landscape must be protected for future societies, but from a sociocultural perspective. The need for more in-depth research into proposals tending to work on the interterritorial connected with the vision of global citizenship is evident, as it is proposed in several recent studies (Trabajo and Cuenca, 2017).

Despite the fact that the perception of individual citizenship, in relation to territorial intelligence, is fully outdated, the vision of social citizenship continues to be the overwhelming majority in the works, in which the symbols and identities of the culture itself are valued and recognized.

\section{Conclusions}

In this study, the importance of the connection between educational research and innovation processes for the training of teachers in the field of heritage education with respect to education for citizenship has been highlighted. The documents analyzed show the importance in the curricular design of innovation proposals through a new selection of contents and interactive methodological aspects, especially with the implementation of a wide diversity of resources, among which the educational use of video games stands out, providing a new way of understanding interaction in the teaching and learning processes of heritage for citizenship education.

In this sense, the impact of the HETEIC project on the training of future teachers is perceived, with the elaboration of 38 final degree projects, in three different degrees, directly related to heritage education and citizenship education.

Likewise, the project has focused a large part of its efforts on determining, for future teachers, the importance of designing heritage education proposals based on holistic and symbolicidentitary visions, which allow the interpretation of societies through heritage on the basis of richer and more complex perceptions.

The connections of heritage with citizenship education and the potential involved in working on emotional and territorial intelligence have been highlighted. However, it has also been evidenced that it is necessary to go much further into the implementation of the approach to territorial intelligence in which the citizenry should be involved through shared management of heritage.

On the other hand, there are some aspects in which some deficits are perceived within the works analyzed. On the one hand, the scant incorporation in the didactic proposals of a vision 
of identitary multiplicity is notable, compared to the affectiveemotional aspects that predominate, as well as the need to go further in the contextualization of heritage elements and their linked contents to improve the understanding of past and present societies.

It is important to bear in mind that the sample is local and small, which may be a limitation in the study. However, the research aims to show the relevance of this type of training, based on innovative and dynamic proposals, with new visions in the selection of content and determination of objectives, aimed at citizen education.

\section{Data availability}

The data sets generated during and/or analyzed during this study are not publicly available due to the intellectual property rights of the authors of the analyzed works, but are available from the corresponding author on reasonable request.

Received: 28 September 2020; Accepted: 18 January 2021; Published online: 05 March 2021

\section{Notes}

1 "Heritage Education for Territorial and Emotional Intelligence for Citizenship". This project analyses the connections between museums and schools to develop a catalogue of good educational practices through which heritage becomes a relevant element for citizenship education through relationships with the management of emotions and territories by students.

2 The parameters that are established for heritage education within the HETEIC project are based on socio-critical, holistic, and symbolic-identity perspectives, always oriented as the ultimate goal to the formation of active and transformative citizenship.

\section{References}

Barghi R, Hamzah A, Rasoolimanesh SM (2020) To what extent Iranian primary school textbooks mirror the philosophy of heritage education? JCHMSD https://doi.org/10.1108/JCHMSD-12-2018-0087

Bisquerra R (2016) Metodología de investigación educativa. La Muralla, Madrid Bisquerra R, Pérez N (2007) Las competencias emocionales. Educ XX1 10:61-82 Cuenca JM (2004) Heritage in social studies education: conceptions and obstacles to integrate its in teaching and learning compulsory education. UMI-ProQuest, Michigan

Cuenca JM, López-Cruz I (2014) La enseñanza del patrimonio en los libros de texto de Ciencias Sociales, Geografía e Historia para ESO. Cult Educ 26(1):19-37. https://doi.org/10.1080/11356405.2014.908663

Cuenca JM, Martín-Cáceres M, Estepa J (2020) Buenas prácticas en educación patrimonial. Análisis de las conexiones entre emociones, territorio y ciudadanía. Aula Abierta 49(1):45-54. https://doi.org/10.17811/rifie.49.1.2020.45-54

Darling-Hammond L, Bransford JD (2005) Preparing teachers for a changing world: what teachers should learn and be able to do. Jossey-Bass, San Francisco

Delgado E, Cuenca JM (2020) Challenges for the Construction of Identities with Historical Consciousness: Heritage Education and Citizenship Education. In: Delgado E, Cuenca JM (eds) Handbook of research on citizenship and heritage education. IGI Global, Hershey, pp 1-25

Domínguez-Almansa A, López-Facal R (2017) Patrimonios en conflicto, competencias cívicas y formación profesional en educación primaria. Rev Educ 375:86-109. https://doi.org/10.4438/1988-592X-RE-2016-375-336

Domínguez-Castillo J (2015) Pensamiento histórico y evaluación de competencias. Graó, Barcelona

Escobar A (2005) El "postdesarrollo" como concepto y práctica social. In: Mato D (ed) Políticas de economía, ambiente y sociedad en tiempos de globalización. Universidad Central de Venezuela, Caracas, pp. 17-31

Estepa J (2019) Investigar para innovar: el caso del Âmbito de Investigación de las sociedades actuales e históricas. REIDICS 4:4-19. https://doi.org/10.17398/ 2531-0968.04.4

Estepa J, Ávila R, Ferreras M (2008) Primary and Secondary Teachers' Conceptions about Heritage and Heritage Education: a Comparative Analysis. Teaching Teach Educ 24(8):2095-2107. https://doi.org/10.1016/j.tate.2008.02.017

Estepa J, Martín-Cáceres M (2020) Heritage in conflict: a way to educate in a critical and participative citizenship. In:Delgado E, Cuenca JM (eds) Handbook of Research on Citizenship and Heritage Education. IGI Global, Hershey, pp. 43-55
Estepa J, Travé G (2012) Investigación e innovación en el proyecto investigando nuestro mundo (6-12). El ejemplo de las sociedades actuales e históricas en la formación inicial de maestros. Revista Electrónica Interuniversitaria de Formación del Profesorado 15(1):113-124. https://revistas.um.es/reifop/article/ view/207711/166451

Feliú M, Hernández-Cardona FX (2011) Enseñar y aprender historia. Graó, Barcelona

Flick U (2018) An introduction to qualitative research. SAGE, London

Fontal O, Ibáñez A (2017) La investigación en educación patrimonial. Evolución y estado actual a través del análisis de indicadores de alto impacto. Revist Educ 375:184-214. https://doi.org/10.4438/1988-592X-RE-2016-375-340

Fuentes C, Sabariego M, Ambros A (2020) Developing social and civic competence in secondary education through the implementation and evaluation of teaching units and educational environments. Humanit Soc Sci Commun 7 (39):1-12. https://doi.org/10.1057/s41599-020-0530-4

García-Pérez FF (2019) Are Teachers Prepared to Educate in Citizenship?: Some Conclusions From Research in Andalusia, Spain. In: Pineda JA, De Alba N, Navarro E (eds) Handbook of research on education for participative citizenship and global prosperity. IGI Global, Hershey, pp. 409-430

Girardot JJ (2013) Des concepts de transition socio-écologique et de résilience aux agendas de transition et aux indicateurs de résilience. Paper presented at the International Conference of Territorial Intelligence "Territorial Intelligence, Socio-Ecological Transition and Resilience of the Territories", BesançonDijon, France, 30-31 May 2013

Gómez-Carrasco C, Miralles P, Fontal O, Ibañez A (2020) Cultural heritage and methodological approaches-an analysis through initial training of history teachers (Spain-England). Sustainability 12:933. https://doi.org/10.3390/ su12030933

Gómez-Carrasco C, Monteagudo J, Moreno JR, Sainz M (2020) Evaluation of a gamification and flipped classroom program used in teacher training: Perception of learning and outcome. PLoS ONE 15(7):e0236083. https://doi.org/ 10.1371/journal.pone. 0236083

Gómez-Carrasco C, Rodríguez-Medina J, Miralles P, Arias VB (2021) Effects of a teacher training program on the motivation and satisfaction of History secondary students. Rev Psicodidact 26(1):45-52. https://doi.org/10.1016/j. psicod.2020.07.002

Gómez-Hurtado I (2019) Hacia un patrimonio inclusivo: Análisis de experiencias didácticas con personas con capacidades diferentes. Paper presented at III Congresso Internacional Envolvimento dos Alunos na Escola: Perspectivas da Psicología y Educaçao. Universidade de Lisboa, Lisboa, 15-17 June 2019

Hauver J (2010) Democracy is a devil's snare: theological certainly in teacher education. Theor Res Soc Educ 38(4):618-639. https://doi.org/10.1080/ 00933104.2010.10473441

Jiménez-Palacios R, Cuenca JM (2015) El uso didáctico de los videojuegos: concepciones e ideas de futuros docentes de ciencias sociales. Clío. History and History Teaching 41: http://clio.rediris.es/n41/articulos/JimenezCuenca2015.pdf

Jiménez-Pérez R, Cuenca JM, Ferreras M (2010) Heritage education: Exploring the conceptions of teachers and administrators from the perspective of experimental and social science teaching. Teaching Teach Educ 26(6):1319-1331. https://doi.org/10.1016/j.tate.2010.01.005

Leenders H, Veugelers W, De Kat E (2008) Teachers' view on citizenship education in secondary education in The Nederlands. Camb J Educ 38:155-170. https:// doi.org/10.1080/03057640802063106

Lobovikov-Katz A (2019) Methodology for Spatial-Visual Literacy (MSVL) in Heritage Education: Application to Teacher Training and Interdisciplinary Perspectives. Revista Electrónica Interuniversitaria de Formación del Profesorado 22(1):41-55. https://doi.org/10.6018/reifop.22.1.358671

López-Arroyo CT (2020) El patrimonio como recurso para el desarrollo formativo de alumnos y profesores. Experiencia didáctica: "Farmington Junior High y su entorno patrimonial". Investigación en la Escuela 101:25-47. https:// revistascientificas.us.es/index.php/IE/article/view/11578

López-Facal R, Miralles P, Prats J, Gómez C (2017) Enseñanza de la historia y competencias educativas. Graó, Barcelona

Lucas L, Delgado E (2018) Educación para una ciudadanía comprometida en la enseñanza de las Ciencias Sociales: ¿Qué piensa el alumnado de un profesor innovador sobre su aprendizaje? Didáctica de las Ciencias Experimentales y Sociales 35:3-16. https://doi.org/10.7203/dces.35.12572

Martínez-Rodríguez M, Fontal O (2020) Dealing with heritage as curricular content in Spain's Primary Education. Curr J 31(1):77-96. https://doi.org/ $10.1002 /$ curj.7

McCulloch G (2004) Documentary research in education, history and the social sciences. RoutledgeFalmer, London

Mendioroz A, Rivero P, Aguilera E (2019) Proposal of teacher training to respond to the High Capacities, in the inclusive school. Profesorado-revista de curriculum y formacion de profesorado 23(1):265-284. https://doi.org/10.30827/ profesorado.v23i1.9154

Molina S, Llonch N, Martínez T (eds) (2016) Identidad, ciudadanía y patrimonio. Educación histórica para el siglo XXI, Trea, Gijón 
Molina S, Miralles P, Ortuño J (2013) Concepciones de los futuros maestros de Educación Primaria sobre formación cívica y ciudadana. Educatio Siglo XXI 31(1):105-126. https://revistas.um.es/educatio/article/view/175361/148441

Munilla C, Marín S (2020) Patrimonio y emociones. Estado de la cuestión desde las perspectivas internacional y nacional. Revista Interuniversitaria de Formación del Profesorado 95(34.1):177-196. https://dialnet.unirioja.es/servlet/ articulo? codigo $=7410805$

No W, Schugurensky D, Brennan A (2017) By the people: participatory democracy, civic engagement and citizenship education. Arizona State University, Phoenix

Pinto H (2017) Interculturality in Heritage Education: challenges and contributions to History teaching. Educar em Revista 63:205-220. https://doi.org/10.1590/ 0104-4060.48650

Poce A, Agrusti F, Re MR (2018) Heritage education and initial teacher training: an international experience. J e-Learn Knowl Soc14(2):127-143. https://doi.org/ $10.20368 / 1971-8829 / 1488$

Prats J (2011) Didáctica de la Geografía y la Historia. Graó, Barcelona

Sáez-López JM, Cózar R, González-Calero JA, Gómez-Carrasco C (2020) Augmented reality in higher education: an evaluation program in initial teacher training. Educ Sci 10(2):26. https://doi.org/10.3390/educsci10020026

Scott JP (ed) (2006) Documentary research. Sage Publications, Thousand Oaks

Trabajo M, Cuenca JM (2017) La educación patrimonial para la adquisición de competencias emocionales y territoriales del alumnado de enseñanza secundaria. PULSO 40:159-174

Trabajo M, Cuenca JM (2020) Student concepts after a didactic experiment in heritage education. Sustainability 12(7):3046. https://doi.org/10.3390/su12073046

Wang CY (2019) Building a network for preserving intangible cultural heritage through education: a study of Indonesian Batik. Int J Art Des Educ 38 (2):398-415. https://doi.org/10.1111/jade.12200

Younghoon H (2019) Practice of Elementary School Cultural Heritage Learning Through Alignment of Curriculum-Instruction-Evaluation: as an example. Stud History Educ 33:211-274. https://doi.org/10.16976/kahe.2019.33.211

\section{Acknowledgements}

This work is the result of the research project "Heritage Education for Territorial and Emotional Intelligence of Citizens" (HETEIC), funded by the Ministry of Universities (EDU2015-67953-P), with co-financing from the European Union ERDF funds,
Network14: Social Science Teaching Research Network (RED2018-102336-T) and the COIDESO Research Centre of the University of Huelva. Paper translated by Neil Macowan (NM Language Services).

\section{Author contributions}

The authors contributed equally to this work.

\section{Competing interests}

The authors declare no competing interests.

\section{Additional information}

Supplementary information The online version contains supplementary material available at https://doi.org/10.1057/s41599-021-00745-6.

Correspondence and requests for materials should be addressed to J.M.C.-L.

Reprints and permission information is available at http://www.nature.com/reprints

Publisher's note Springer Nature remains neutral with regard to jurisdictional claims in published maps and institutional affiliations.

(c) (i) Open Access This article is licensed under a Creative Commons Attribution 4.0 International License, which permits use, sharing, adaptation, distribution and reproduction in any medium or format, as long as you give appropriate credit to the original author(s) and the source, provide a link to the Creative Commons license, and indicate if changes were made. The images or other third party material in this article are included in the article's Creative Commons license, unless indicated otherwise in a credit line to the material. If material is not included in the article's Creative Commons license and your intended use is not permitted by statutory regulation or exceeds the permitted use, you will need to obtain permission directly from the copyright holder. To view a copy of this license, visit http://creativecommons.org/ licenses/by/4.0/.

(c) The Author(s) 2021 